\title{
A NEW SPECIES OF STYLIDIUM (STYLIDIACEAE) FROM THE SYDNEY REGION
}

\author{
Mary M. Hindmarsh AND D. F. Blaxell
}

(Accepted 14.12.1977)

\section{ABSTRACT}

Hindmarsh, Mary M. (School of Botany, University of New South Wales, P.O. Box I, Kensington, Australia 2033) and Blaxell, D. F. (National Herbarium of New South Wales, Royal Botanic Gardens, Sydney, Australia 2000) 1978. A New Species of Stylidium (Stylidiaceae) from the Sydney Region. Telopea 1 (5): 365-370, Pl. XII-Stylidium productum is described from the Central Coast and Tablelands region of New South Wales and distinguished from the widespread S. graminifolium.

Stylidium graminifolium Sw. ex Willd. is recorded as a widespread species in the coastal and the mountain regions of New South Wales; it also occurs in Queensland, Victoria, South Australia and Tasmania. Field observations near Sydney indicate that two distinct species have been included under this name.

$S$. graminifolium s. str. has crowded basal leaves on a short condensed stem. Our observations have shown that the leaves have stomata in two bands, one on either side of the mid-vein on both the adaxial and the abaxial surfaces (Fig. 1a). This stomatal arrangement is a consistent character not previously recorded. The name Stylidium productum is proposed for the new species; the specific epithet refers to the presence of an elongated vegetative stem. The leaves have stomata in two bands on the abaxial surface only (Fig. 1b).

The plants we now distinguish as $S$. productum have been included within the concept of $S$. graminifolium by previous New South Wales authors (Moore \& Betche 1893; Beadle, Evans \& Carolin 1963, 1972). Specimens examined by Bentham (at $\mathrm{K}$ and $\mathrm{BM}$ ) include both species, but all the specimens of $S$. productum are terminal pieces that do not show the elongated nature of the stem. This may explain his phrase ". . . or shortly proliferous, rarely lengthening to 4 or 5 in." (Bentham 1869). Moore \& Betche added to their description ". . . the stems occasionally elongated and with tufted leaves", which would indicate that these authors observed the long leafy stems at least in some plants that they were referring to Candollea serrulata Labill. ( $\equiv$ Stylidium graminifolium Sw. ex Willd.).

Mildbraed (1908, p. 73) described S. graminifolium var. caulescens and his description could fit $S$. productum. Mildbraed's name has not been adopted, to our knowledge, in any Australian herbarium. The reason may be that he cited only one specimen, "Queensland?: "North Shore" (Leichardt [sic]!)" and added the comment, "An specimen monstrosum?"

Erickson (1958) gave a translation of the original Latin description of $S$. graminifolium var. caulescens Mildbraed, and translated Mildbraed's comments as "Possibly an unnatural specimen. Qld., North Shore." Examination of specimens in Australian and overseas herbaria has not revealed the existence of a Leichhardt specimen from any locality and all material from areas other than the Sydney region 
has proved to be $S$. graminifolium s. str.; "North Shore" was not an unusual or uncommon locality for Leichhardt to have written on a specimen label. During his years in Australia (1842-1848) the largely undeveloped country on the north side of Port Jackson (Sydney Harbour) extending to Broken Bay was (and still is) referred to as the "North Shore". Therefore it is highly probable that Leichhardt's specimen of $S$. graminifolium var. caulescens could have been collected in the Sydney district. ${ }^{*}$ It is considered desirable however, to base the species on a new type and provide it with an independent epithet.
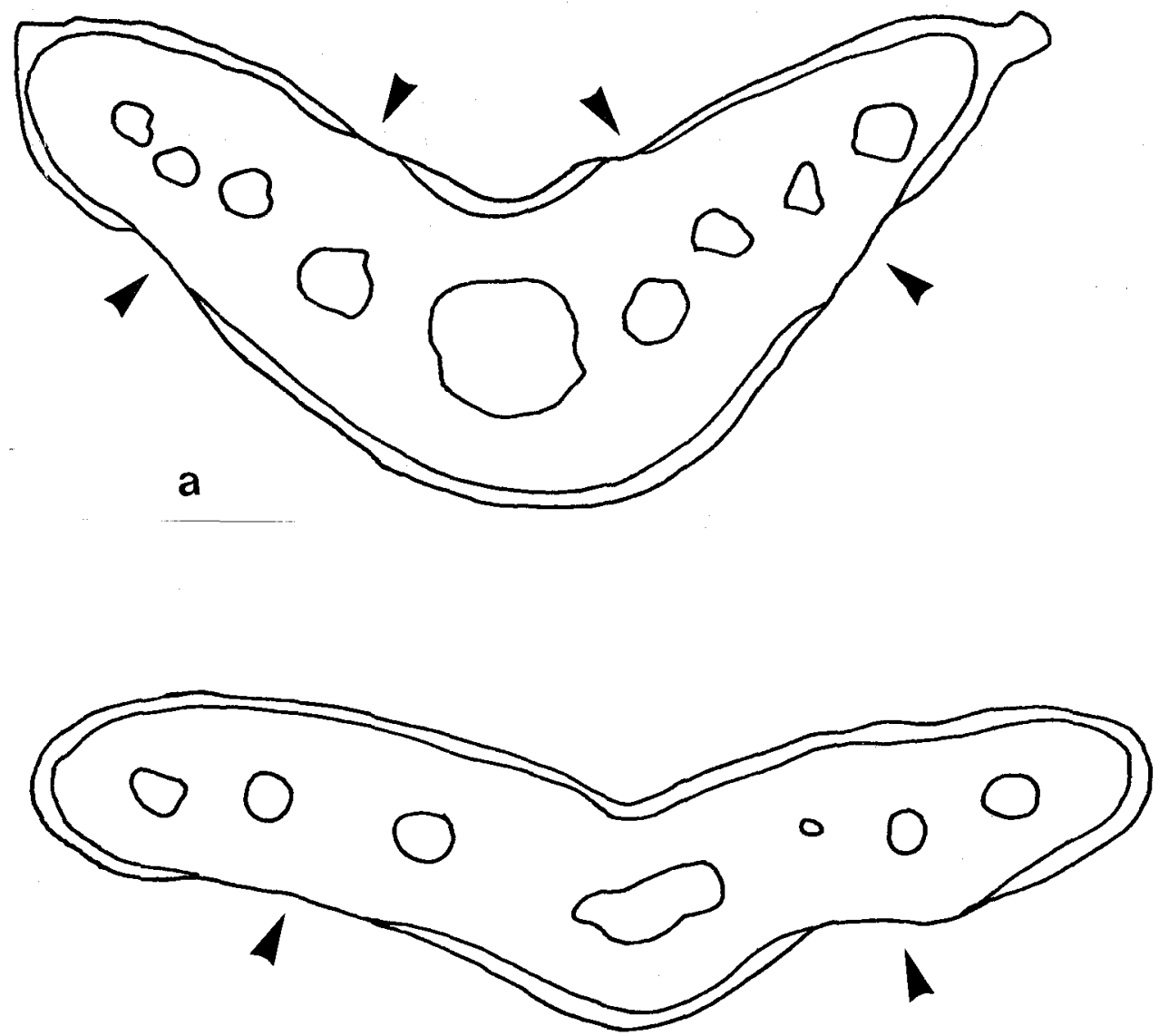

b

Fig. 1. Transverse sections of leaf of - a. Stylidium graminifolium and b. Stylidium productum. Arrows indicate position of thin-walled epidermal cells with stomata

* In the herbarium of the British Museum (Natural History) there are three specimens, collected by Robert Brown in 1803-4, which are $S$. productum. Two of these, collected at Lane Cove in October 1803 , were labelled by Brown "Lobeliastrum nemorale", and the third, collected from the Grose River in December 1804, was also labelled by him, "Stylidium graminifolium prodr 568 var nemorale". He had obviously distinguished our new species from S. graminifolium but later made no mention of it (Brown 1810).

A specimen of $S$. productum in Herb. Webbianum at Florence is labelled " $S$. staticifolium Labill., Nov. Holl." No record of publication of this epithet by Labillardière or later authors has been found. 
Stylidium productum $M$. Hindmarsh et $D$. Blaxell nom. et stat. nov.

Synonym: Stylidium graminifolium Sw. ex Willd. var. caulescens Mildbraed, Pflanzenreich 4 (35): 73 (1908).

$S$. productum Hindmarsh et Blaxell; differt a $S$. graminifolium $\mathrm{Sw}$. ex Willd. caulis elongatis, foliis pseudoverticillatis, non nisi in facie abaxiali stomatibus instructis.

Holotype: Cliff Drive, Katoomba, New South Wales, M. M. Hindmarsh \& D. F. Blaxell' DFB 1056, 12.1972 (NSW). Plate XII. IsOTYPES: K, CANB, MEL, PERTH, UNIVERSITY OF NEW SOUTH WALES, RSA.

The new species differs from the more widespread $S$. graminifolium in the following characters:

1. stems up to $1 \mathrm{~m}$ long with leaves scattered along the entire length but crowded at intervals. The older region of the stem may be leafless due to abscission.

2. adventitious roots developed from the long stems, which also produce new plants at intervals.

3. stomata in a longitudinal band on each side of the mid-vein on the abaxial surface only (Fig. 1). Some magnification is necessary to observe this clearly in some specimens.

4. leaf bases with a small prolongation up to a few mm long, on the abaxial surface (Fig. 2).

5. a more restricted flowering period: S. graminifolium has been found in New South Wales flowering from August until the end of January, whilst $S$. productum has a flowering period from November to the middle of January.

6. labellum broadly obovate, not narrowed to a rounded point at the tip.

Cytology: In Tasmania, both diploid $(2 n=30)$ and tetraploid $(2 n=60)$ plants of S. graminifolium have been found (W. Jackson 1972, pers. comm.) but in New South Wales the plants we have examined so far are tetraploid, except for two populations. One is near Gunderman, between Wisemans Ferry and Central Mangrove, and the other is at Wentworth Falls. Counts of $S$. productum to date are all tetraploid. Cytological investigations are continuing.

Distribution: This new species is known to occur only on soils derived from the Hawkesbury and Narrabeen Sandstones of the Central Coast and Tablelands of New South Wales: the most northern populations observed by the authors being on the Pacific Highway near Gosford (Central Coast) and near Kandos Weir east of Kandos (Central Tablelands). These latter populations are also the most western known to us. The southernmost populations are around Cataract Dam, northwest of Wollongong. Around Sydney and on the Blue Mountains it is extremely common on skeletal soils on hillsides, on sandstone cliffs, roadside cuttings and with outcropping sandstone, in many localities, but has not been found on alluvial sands or on heavier soils derived from the Wianamatta Group. In the same region $S$. graminifolium occurs on deep sandstone soils and alluvial sands as well as on heavier Wianamatta soils, sometimes in swampy conditions, but in other parts of New South Wales, in Queensland, Victoria, Tasmania and South Australia this species grows on a variety of soil types from coastal sands to volcanic soils and over a wide altitudinal range (to $2100 \mathrm{~m}$ ). Although $S$. productum favours the soils of the Hawkesbury and Narrabeen Sandstones round Sydney, it has not been found in apparently similar sites north and south of Sydney where the soils are derived from Permian Sandstones. 


\section{Plate XII}

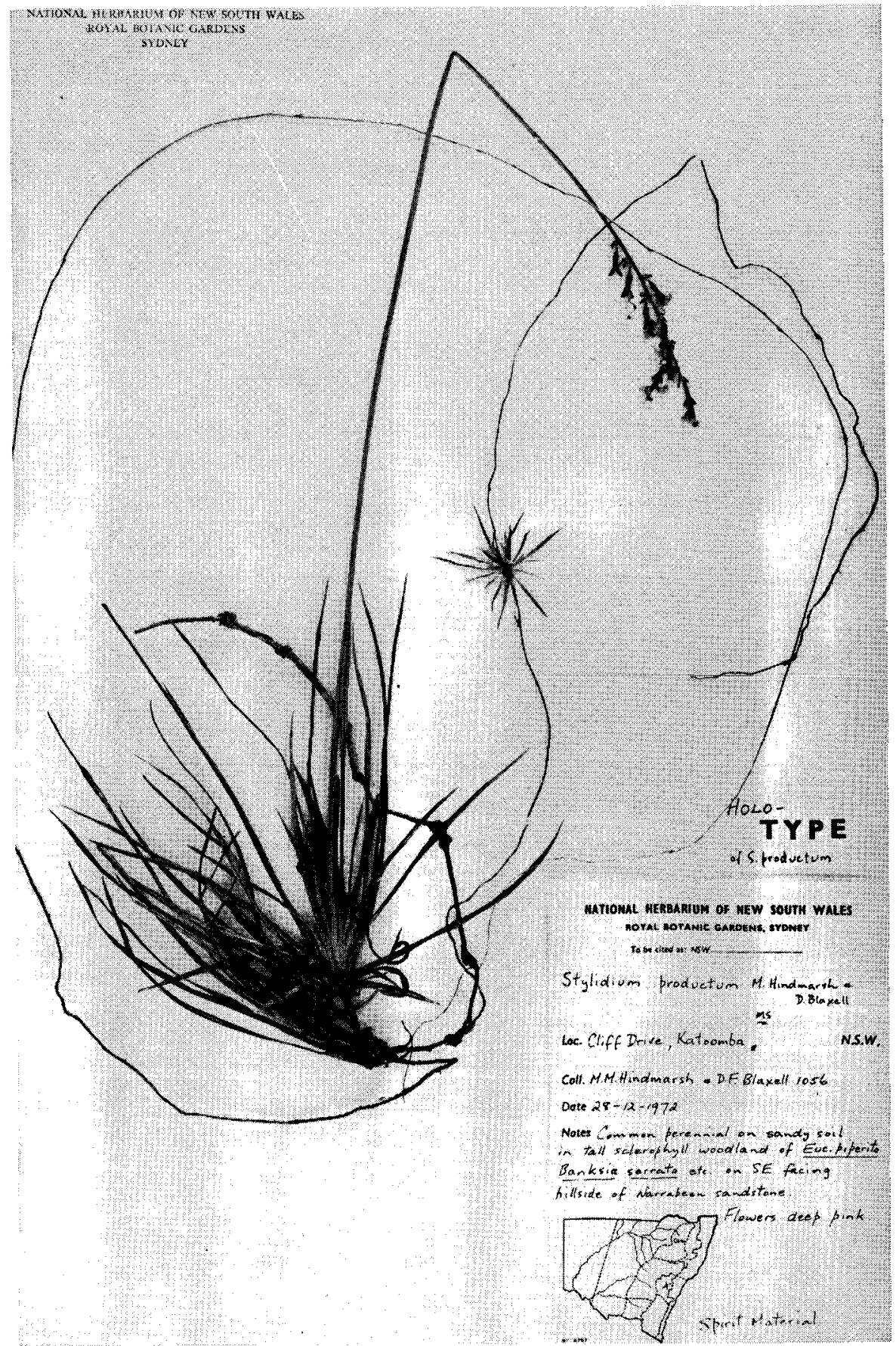

Holotype of Stylidium productum M. Hindmarsh et D. Blaxell 
In three places, Hartley Vale, Wentworth Falls and north of Windsor near Putty, the two species grow less than $200 \mathrm{~m}$ apart but in different edaphic conditions. No hybridization between the species has been observed to date but these areas will be examined further.
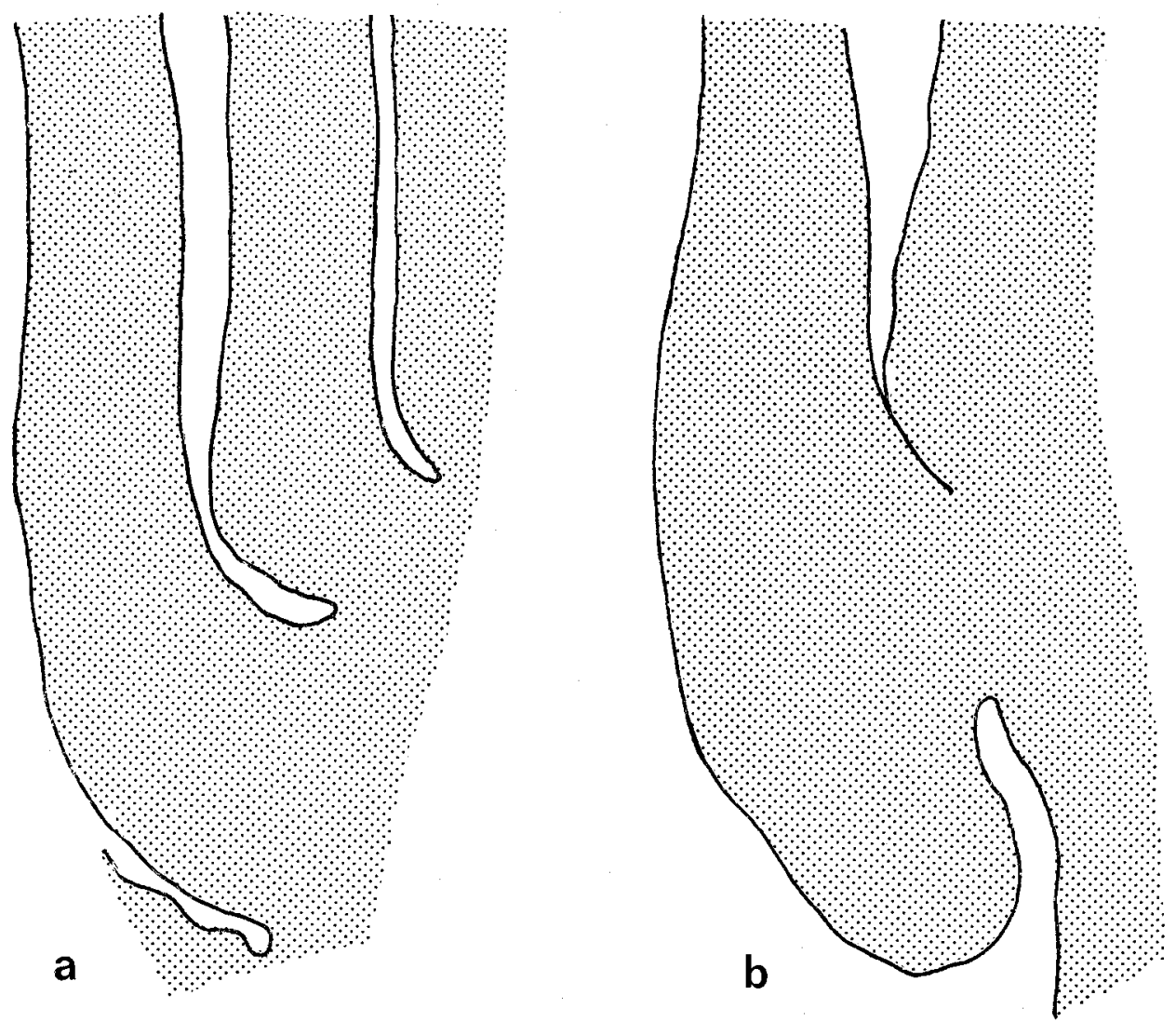

Fig. 2. Vertical sections through leaf bases and part of stem of-a. Stylidium graminifolium and b. Stylidium productum.

\section{ACKNOWLEDGEMENTS}

We wish to thank Mrs Elma Reilly, Mr Patrick Matthew and Miss Isobel Bowden, for considerable assistance with collections and observations in the field, Mr D. Woodford, who in a student project made some of the preliminary observations in this work, also Dr L. A. S. Johnson and Dr Barbara Briggs for helpful criticism of the manuscript and assistance with the Latin diagnosis. 


\section{LITERATURE CITED}

Beadle, N. C. W., Evans, O. D., and Carolin, R. C., 1963-Handbook of the Vascular Plants of the Sydney District and Blue Mountains. Brown Gem Print, Armidale.

Beadle, N. C. W., Evans, O. D., and Carolin, R. C., 1972-Flora of the Sydney Region. A. H. \& A. W. Reed, Sydney.

Bentham, G., 1869-Flora Australiensis. Vol. 4. Lovell Reeve, London.

Brown, R., 1810-Prodromus Florae Novae Hollandiae et Insulae Van Diemen. J. Johnson \& Son, London.

Erickson, R., 1958--Triggerplants. Paterson Brokensha, Perth.

Mildbraed, J., 1908--Stylidiaceae. In A. Engler, Pflanzenreich 4 (35): 1-98. Engelmann, Leipzig.

Moore, C., and Betche, E., 1893-Handbook of the Flora of New South Wales. Government Printer, Sydney. 